\title{
Capital Gains Taxation in the United States: Realizations, Revenue, and Rhetoric
}

IN 1985, individuals filing U.S. tax returns reported $\$ 166.4$ billion of long-term capital gains in excess of short-term capital losses. ${ }^{1}$ The following year Congress enacted a significant increase in capital gains taxes effective in 1987, and capital gains realizations for 1986 nearly doubled, to $\$ 324.8$ billion. ${ }^{2}$ That investors' expectations of tax changes would alter their realization practices markedly comes as no surprise. How changing rates would affect tax revenues and realizations in the longer run is not as obvious.

Largely as a result of the capital gains tax increase of 1986, the U.S. presidential campaign of 1988 saw an intensification of a continuing debate over capital gains taxes. Proponents of reducing capital gains tax rates argue that lower rates would reduce economic distortions and encourage investment in new enterprises while raising tax revenue by increasing realization of gains more than enough to offset the rate reduction. Opponents of cutting capital gains tax rates believe it would

I am grateful to Gerald Auten, Bill Carter, Harvey Galper, Jane Gravelle, Robert Kalish, Joe Minarik, Larry Ozanne, Jim Poterba, Joel Slemrod, Eric Toder, and members of the Brookings Panel for providing useful information and comments on previous drafts, and to the National Science Foundation and the Penn Institute for Law and Economics for financial support.

1. Congressional Budget Office, How Capital Gains Tax Rates Affect Revenues: The Historical Evidence (CBO, March 1988), table 4.

2. U.S. Internal Revenue Service, Statistics of Income for 1986: Individual Income Tax Returns, advance data table 1 (IRS, November 28, 1987). Like the CBO measure, this includes the pre-exclusion value of the small amount of capital gain distributions reported directly on Form 1040 rather than Schedule D. 
reduce rather than raise revenue and see one of its main effects as increasing the after-tax income of the wealthy. ${ }^{3}$

How responsive realizations of capital gains are to tax rates has been the subject of continuing policy debate. A study published by the Treasury's Office of Economic Policy in June simulated the effects of reductions in long-term capital gains tax rates enacted in 1978 and 1981, and concluded that tax revenue increased during 1979-85 as a result of these tax cuts-a finding that was immediately challenged.$^{4} \mathrm{~A}$ similarly contentious debate arose 10 years ago, when President Carter's proposal to raise capital gains taxes led to the capital gains tax reductions of the 1978 Revenue Act. ${ }^{5}$

This paper begins with a review of the recent dispute and then moves to a more general discussion both of whether reducing capital gains tax rates will raise or lower revenue and of whether cutting the capital gains tax is sensible government policy. Such a discussion must go well beyond the limited issues of measuring the revenues from the capital gains tax alone. Most important, taxing income from other sources at a higher rate than long-term capital gains provides incentives for individuals to choose investment assets on the basis of minimizing taxes and to divert income to capital gains form. A full treatment of the revenue consequences of a capital gains tax cut would thus require looking at the income tax lost in addition to the capital gains tax lost or gained. Taking account of such changes in individuals' behavior would also be important in considering broader questions of the economic efficiency of the tax system.

Several conclusions follow from a careful consideration of the relevant

3. See Jane G. Gravelle, "Will Reducing Capital Gains Taxes Raise Revenue?" Tax Notes, vol. 36 (July 27, 1987), pp. 419-24; and Jane G. Gravelle and Lawrence B. Lindsey, “Capital Gains,"' Tax Notes, vol. 38 (January 25, 1988), pp. 397-405.

4. Michael Darby, Robert Gillingham, and John S. Greenlees, "The Direct Revenue Effects of Capital Gains Taxation: A Reconsideration of the Time-Series Evidence," Treasury Bulletin (June 1988); Joseph J. Minarik, "The New Treasury Capital Gains Study: What Is in the Black Box?" Tax Notes, vol. 39 (June 20, 1988), pp. 1465-71; Michael Darby, Robert Gillingham, and John S. Greenlees, "The Black Box Revealed: Reply to Minarik," Tax Notes, vol. 40 (July 25, 1988), pp. 413-16.

5. John Yinger, "Feldstein on Capital Gains Realizations," Council of Economic Advisors Staff Paper (September 1978); Martin Feldstein, "The Appropriate Taxation of Capital Gains: A Response to John Yinger," Tax Notes, vol. 7 (October 30, 1978), pp. 507-08; William D. Nordhaus, "Claimed Effects of Gains Tax Cuts: A Mirage?" Tax Notes, vol. 7 (December 4, 1978), p. 652. 
econometric, theoretical, and policy issues. First, tax considerations heavily influence investors' decisions about when to realize capital gains. Most noticeably, if capital gains taxes are expected to fall (rise) next year, capital gains realizations will be postponed (accelerated) this year. Second, empirical work to date has failed to distinguish adequately between such temporary effects of tax changes on realizations and the permanent effects of different tax rates. There is little convincing evidence of a strong permanent effect. Third, most recent research has focused on the effect of lower capital gains tax rates on revenues from the capital gains tax. It is theoretically possible that increased realizations would more than offset the effect of lower rates on tax revenues. But the existing time series evidence is that it is just as possible that the responses of investors to a tax cut will reinforce, rather than offset, the effect of lower rates in reducing revenues. Fourth, whatever their accuracy, estimated changes in individual capital gains tax payments associated with capital gains tax rate changes are a poor indicator of the efficiency or incidence of such policies. Finally, other changes in the treatment of capital gains are better suited to achieve the efficiency objectives embraced by some proponents as the main reason for reducing tax rates on realized long-term capital gains.

\section{The Recent Debate}

By and large, investors can choose when to realize their capital gains. Since capital gains are taxed only when they are realized, realizations will naturally be sensitive to taxation. Table 1 gives the value of longterm capital gains realized each year during 1954-87, the ratio of those capital gains to the Standard and Poor's 500 stock price index (as a way to scale the value of the gains), and the average marginal tax rates that applied to those gains. Aside from the unprecedented increase in realizations in 1986 that preceded the largest increase in capital gains taxes during the period, the most significant increase in realizations occurred in 1979, after the tax reduction passed in 1978. The 1979 episode lent support to the view that tax cuts do increase realizations substantially. But the huge increase in realizations in 1986 suggests that the expected change in rates, rather than the level of rates, may be the important factor governing realizations. Nevertheless, analysts have 
Table 1. Capital Gains and Marginal Tax Rates, 1954-87

\begin{tabular}{cccc}
\hline & $\begin{array}{c}\text { Capital } \\
\text { gains } \\
\text { (billions } \\
\text { of dollars) }\end{array}$ & $\begin{array}{c}\text { Ratio of } \\
\text { gains to } \\
\text { S\& } 500 \\
\text { index }\end{array}$ & $\begin{array}{c}\text { Marginal } \\
\text { tax rate } \\
\text { (percent) }^{\mathrm{b}}\end{array}$ \\
\hline 1954 & 7.0 & 0.24 & 17.3 \\
1955 & 9.7 & 0.24 & 17.7 \\
1956 & 9.6 & 0.21 & 18.0 \\
1957 & 8.2 & 0.18 & 17.2 \\
1958 & 9.3 & 0.20 & 17.3 \\
1959 & 12.9 & 0.22 & 17.1 \\
1960 & 11.7 & 0.21 & 16.7 \\
1961 & 15.7 & 0.24 & 17.1 \\
1962 & 13.6 & 0.22 & 16.8 \\
1963 & 14.5 & 0.21 & 16.9 \\
1964 & 17.0 & 0.21 & 16.2 \\
1965 & 20.8 & 0.24 & 16.1 \\
1966 & 21.8 & 0.26 & 16.2 \\
1967 & 27.3 & 0.30 & 16.7 \\
1968 & 35.8 & 0.36 & 18.6 \\
1969 & 32.6 & 0.33 & 18.8 \\
1970 & 21.3 & 0.26 & 19.5 \\
1971 & 28.2 & 0.29 & 19.9 \\
1972 & 36.1 & 0.33 & 20.1 \\
1973 & 35.8 & 0.33 & 19.5 \\
1974 & 30.0 & 0.36 & 19.5 \\
1975 & 30.7 & 0.36 & 20.1 \\
1976 & 39.2 & 0.38 & 21.9 \\
1977 & 44.4 & 0.45 & 22.2 \\
1978 & 48.9 & 0.51 & 22.7 \\
1979 & 71.3 & 0.69 & 18.1 \\
1980 & 70.8 & 0.59 & 18.6 \\
1981 & 78.3 & 0.61 & 16.8 \\
1982 & 87.1 & 0.73 & 14.8 \\
1983 & 117.3 & 0.73 & 14.4 \\
1984 & 135.9 & 0.85 & 14.0 \\
1985 & 166.4 & 0.89 & 13.9 \\
1986 & 324.8 & 1.37 & 14.4 \\
1987 & n.a. & n.a. & $25.4^{\mathrm{c}}$ \\
\hline
\end{tabular}

Sources: Congressional Budget Office, How Capital Gains Tax Rates Affect Revenues: The Historical Evidence (CBO, March 1988), tables 3 and 8. Capital gains for 1985 are corrected, and those for 1986 are calculated, using the CBO method, from U.S. Internal Revenue Service, Statistics of Income for 1986: Individual Income Tax Returns (IRS, November 28, 1987), advance data table 1.

n.a. Not available.

a. Long-term gains net of short-term losses from Schedule D, plus long-term gains appearing directly on Form 1040.

b. Weighted average marginal tax rate on long-term capital gains.

c. Based on $\mathrm{CBO}$ estimates of marginal tax rates, pre- and post-tax reform. 
tried to draw conclusions about the effect of rate levels, mainly from models that ignored the effect of expected changes in rates.

Much of the empirical research on capital gains taxation has been based on cross-section microeconomic data. In many ways, the household is preferable to the economy as a whole as the unit to study, since households differ substantially in both tax status and behavior. However, if panel data that track individual households over time are unavailable, time series data make it possible to assess the impact of actual tax changes. Recent research and debate have been based on aggregate time series, with some studies predicting that a capital gains tax cut would raise revenue and others that it would lower it. ${ }^{6} \mathrm{It}$ is useful to begin with the following equation, estimated using annual data over the sample 1954-85 (with $t$-statistics in parentheses):

$$
\begin{aligned}
(1) \ln (L T G)= & -8.84+1.17 \ln (P R I C E)+0.50 \ln (R C E) \\
& (-7.04) \quad(5.52) \\
& +1.02 \ln (R G N P)+2.01 d \ln (R G N P) \\
& (3.01) \quad(2.51) \\
& -0.56 \ln (M T R), \\
& (-2.48) \\
& \quad \text { Durbin-Watson }=1.37 ; \bar{R}^{2}=0.985 .
\end{aligned}
$$

Equation 1 is a log-log specification, with dependent and independent variables entering in logarithmic form. $L T G$ is realized long-term gains net of short-term losses, PRICE is the GNP deflator, RCE is the real value of corporate equity held at the end of the year by households (as computed by the Federal Reserve's Flow of Funds Division), RGNP is

6. Aside from Darby, Gillingham, and Greenlees, "Direct Revenue Effects of Capital Gains Taxation," Lawrence B. Lindsey, "Capital Gains: Rates, Realizations and Revenues," in Martin Feldstein, ed., The Effects of Taxation on Capital Accumulation (University of Chicago Press, 1987), also suggests that a reduction in capital gains tax rates would raise revenue. Lindsey creates a panel from aggregate statistics by considering separate income classes at each date as separate observations. The major piece finding that capital gains tax cuts reduce revenue is CBO, How Capital Gains Tax Rates Affect Revenues. Also see CBO, Effects of the 1981 Tax Act on the Distribution of Income and Taxes Paid (CBO, August 1986); U.S. Treasury, Office of Tax Analysis, Report to the Congress on the Capital Gains Tax Reductions of 1978 (Treasury, September 1985); and Gerald Auten, "Capital Gains: An Evaluation of the 1978 and 1981 Tax Cuts," in Charls E. Walker and Mark A. Bloomfield, eds., New Directions in Federal Tax Policy for the 1980s (Ballinger, 1983), pp. 121-48. 
real GNP, and $M T R$ is the weighted average household marginal tax rate on long-term capital gains.

There are many ways to construct the capital gains and marginal tax rate variables used in equation 1 . The definitions used here are taken from the March 1988 Congressional Budget Office study, and the equation itself replicates one of that study's equations. ${ }^{7}$ The June 1988 Treasury study estimates the same equation with somewhat different definitions for the dependent and tax rate variables, arriving at a coefficient for the logarithm of the latter of -0.67 , rather than $-0.56 .^{8}$ Even though these differences in results do not change one's qualitative conclusion about the behavior of capital gains realizations, it is useful to review the issue of variable construction because it highlights some of the difficulties of using aggregate time series.

Throughout the 1954-85 sample period (ending only with the Tax Reform Act of 1986), tax law made a distinction between long-term and short-term capital gains, with long-term gains (those associated with assets held for more than six months, nine months for a one-year transition period, or one year, depending on the date) being subject to favorable tax treatment. Researchers commonly focus on long-term gains, largely because most realized gains are long-term ones. ${ }^{9}$ But capital losses must also be dealt with. The tax law treats gains and losses asymmetrically, with gains being fully taxable but losses, after offsetting gains, being subject to a limitation on their deductibility against other income. ${ }^{10}$ Aggregate studies typically exclude taxpayers with net long-

7. Equation A-14, p. 88. There are slight differences in the second decimal place of some coefficients, apparently due to data revisions. The constants also differ; because of the log-log specification, the choice of units affects the constant.

8. Darby, Gillingham, and Greenlees, "Direct Revenue Effects," table 3, equation 4.

9. In 1985, for example, individual taxpayers with net long-term capital gains (after deduction of long-term losses and loss carryovers) reported total long-term gains of $\$ 168.7$ billion. Short-term gains measured in the same manner were only $\$ 6.1$ billion. See U.S. Internal Revenue Service, Statistics of Income for 1985: Individual Income Tax Returns, table 1.4, p. 22.

10. A taxpayer first matches gross long-term losses against gross long-term gains and gross short-term losses against gross short-term gains to arrive at a net long-term position (gain or loss) and a net short-term position. If either position shows a loss, the taxpayer then offsets net short-term losses against net long-term gains or net long-term losses against net short-term gains. Net long-term gains (until 1986, after a partial exclusion) and net short-term gains are then fully taxable. Only taxpayers with net overall losses then face an overall $\$ 3,000$ limit on use of losses to offset other taxable income, with the limit applied 
term losses from their analysis, on the grounds that such taxpayers are likely to face loss limitations and be little affected by changes in statutory marginal tax rates. The June 1988 Treasury study attempts to explain net long-term gains plus net short-term gains, while the March 1988 CBO study excludes short-term gains and goes one step further by adding capital gain distributions not reported separateiy. Though one could debate their merits, none of these adjustments is especially important quantitatively.

Finally, it is necessary in aggregate regressions to choose "the" marginal tax rate. $\mathrm{CBO}$ uses a weighted-average marginal tax rate, with weights based on predicted capital gains realizations to avoid simultaneity bias. Treasury uses a high-income average marginal tax rate, based on a sample of taxpayers with more than $\$ 200,000$ (1982 dollars) of adjusted gross income. A similar alternative tax rate measure was also considered by CBO. ${ }^{11}$

Consider the implications of equation 1 for investor behavior. Given the log-log specification, one may interpret the coefficient of the tax rate term as the elasticity of realizations with respect to the tax rate. When average and marginal tax rates are equal, the direct revenue from this uniform tax will increase with a tax cut if and only if this elasticity is less than -1 , that is, has an absolute value greater than 1 . Though their exact estimates differ, both Treasury and CBO find elasticities considerably below 1 in absolute value. Yet, in its simulations of the effects of the 1978 and 1981 tax cuts based on its version of this equation, Treasury finds that each tax cut raised tax revenue in each but the first year after enactment. ${ }^{12}$ There is, of course, nothing particularly special about the revenue break-even point; cutting a distortionary tax could lose revenue and still make good economic sense. However, the current concern over budget deficits, together with a continuing quest for the elusive free lunch, seems to have affected the grounds of public debate on this issue.

to the sum of net long-term losses (again, until 1986 after a partial exclusion) and shortterm losses. For further discussion, $\rightarrow$ : James M. Poterba, "How Burdensome Are Capital Gains Taxes? Evidence from the United States," Journal of Public Economics, vol. 33 (July 1987), pp. 157-72.

11. Even in cross-section studies based on individual household data, the choice of appropriate tax rate is not simple, since each individual faces a tax schedule rather than a single tax rate. This issue is discussed more fully below.

12. Darby, Gillingham, and Greenlees, "Direct Revenue Effects," table 5, col. 4. 
The key to Treasury's estimate that revenues will increase with a cut in capital gains taxes, despite a realization elasticity well below unity, is its implicit assumption that the capital gains tax cuts of 1978 and 1981 not only lowered marginal tax rates but also increased average tax rates relative to marginal tax rates. Revenue equals the level of realizations, which depends on the marginal tax rate, multiplied by the average tax rate. Given the marginal tax rate, therefore, an increase in the average tax rate raises revenue, regardless of the investor response to marginal tax rates: it is a lump-sum tax. A policy that cuts marginal tax rates more than average tax rates may be seen as a standard tax cut to which the unitary-elasticity rule applies, combined with a lump-sum tax. If the lump-sum tax is large enough, it can lead to an overall increase in revenue even for a very small increase in realizations.

Although the gap between marginal and average tax rates has actually narrowed during the past several years, it has not done so because of changes in capital gains taxes. Yet Treasury's methodology attributes the entire change in average tax rates following the 1978 and 1981. acts to the capital gains provisions of these acts. ${ }^{13}$

There are clearly other reasons why the gap between average and marginal tax rates has narrowed. Calculations by the Congressional Budget Office find that bracket creep alone (which does not affect the aggregate marginal tax rate used in the Treasury study) raised capital gains tax revenues between 1981 and 1984 by $\$ 0.8$ billion, or 4 percent of 1984 tax revenue from this source. ${ }^{14}$ An additional $\$ 1.3$ billion is attributable to the minimum tax provisions introduced in 1982, which are also (given Treasury's specification) largely inframarginal increases in average tax rates between 1980 and 1984 that have little to do with the capital gains provisions of the 1981 act. Omitting these two sources of 1984 revenue from the comparison, CBO estimates that the 1981 capital gains tax cut reduced 1984 long-term capital gains tax revenues by $\$ 1.7$ billion. CBO estimates that revenue would have fallen much more- $\$ 5.6$ billion-absent any increase in capital gains realizations, the so-called "static" revenue loss.

13. Treasury, Capital Gains Tax Reductions of 1978. For example, Treasury uses the actual 1980 average tax rate as an estimate of what the 1984 average tax rate would have been without the 1981 capital gains tax cut.

14. CBO, "Simulating the Revenue Effects of Changes in the Taxation of Capital Gains," Staff Working Paper (November 1988). I am grateful to Eric Toder and Larry Ozanne of CBO for providing me with the preliminary figures. 
One could reasonably conclude from the recent debate that a capital gains tax cut would not raise revenue but would offset a substantial fraction of the impact of lower rates through increased realizations. However, it is important to question whether equations such as equation 1 are properly specified and whether increases in current realizations of long-term gains have revenue implications beyond those directly measured.

\section{A Closer Look at the Time Series Evidence}

Econometric specification of aggregate equations explaining capital gains realizations involves two important issues. One is inference problems associated with the time series properties of aggregate series. The other, more central, point is the question of how to model the effects of tax rates on realizations to permit a realistic characterization of taxpayer behavior.

Several analysts have tried to estimate the effects of taxation on longterm capital gains realizations using annual postwar time series. Virtually none of their equations includes even a time trend, and none of the authors seems to worry about the use of highly nonstationary time series for prediction and hypothesis testing.

Of the potentially serious problems associated with nonstationary time series regressions, perhaps the most important is that test statistics such as $t$-ratios are not estimated correctly and significance levels may be greatly overstated. ${ }^{15} \mathrm{~A}$ second problem is that such regressions are dominated by long-run relationships among the dependent and independent variables. To the extent that tax rates and realizations are each affected by omitted variables (such as the population's size and age structure and per capita income) that drive the underlying nonstationarity, the direct effect of tax rates on realizations will be estimated with bias.

To explore the importance of these problems in the current case, I begin with another equation based on the March 1988 CBO study, similar to equation 1 but with a time trend added and with the marginal tax rate

15. This was first emphasized using Monte Carlo results $\rightarrow$ C. W. J. Granger and P. Newbold, "Spurious Regressions in Econometrics," Journal of Econometrics, vol. 2 (1974), pp. 111-20. Also $\rightarrow$ P. C. B. Phillips, "Understanding Spurious Regressions in Econometrics," Journal of Econometrics, vol. 33 (December 1986), pp. 311-40. 
rather than its logarithm used as an explanatory variable. ${ }^{16}$ This equation is reported in table 2 as equation 2 . In this semilog form, the implied elasticity of the dependent variable with respect to the tax rate is the coefficient of the tax rate multiplied by the tax rate; the higher the coefficient in absolute value, the lower the "revenue-maximizing" tax rate at which the elasticity equals -1 . For example, the revenuemaximizing tax rate implied by equation 2 is 34.6 percent. ${ }^{17}$

Equation 2, like equation 1, is characterized by a very high $\bar{R}^{2}$ and a low Durbin-Watson statistic, as one would expect from a regression based on nonstationary time series. The Durbin-Watson statistic is raised somewhat by the inclusion of the time trend, which proves to be a significant explanatory variable. However, using a time trend does not solve the potential problems of using nonstationary regressors that may remain nonstationary even after being detrended. Therefore, it is useful to compare these results with those obtained when equation 2 is differenced.

The differenced version of equation 2 is reported as equation 3 in table 2. Perhaps most important, the coefficient of the marginal tax rate increases with differencing, implying a revenue-maximizing tax rate of 23.4 percent. As expected, there is a considerable decline in the fraction of the dependent variable's variance explained by the regression. Along with this change comes a reduction in the $t$-statistics of some of the nonstationary variables, notably the GNP deflator, real GNP, the proportional change in real GNP, and the time trend itself (which appears as a constant in the differenced specification). In addition, the DurbinWatson statistic increases and indicates little serial correlation in subsequent specifications.

\section{CHANGES IN TAX RATES}

Previous studies have typically added the lagged tax rate as an explanatory variable to these basic equations to determine the extent to

16. This semilog specification is chosen because it is more common in the literature, thus making comparisons easier. Qualitatively similar results hold for the log-log specification.

17. In light of the preceding discussion of the importance of average as well as marginal tax rates in determining whether tax cuts raise revenue, it is clearly misleading to refer to the marginal tax rate associated with a unitary elasticity as revenue-maximizing. However, this is the terminology that has been adopted in the literature. 
which the tax rate responsiveness of capital gains realizations is temporary rather than permanent. Equation 4 in table 2 is typical of such equations, including the change in tax rates over the past year as well as the current tax rate. This equation also substitutes the value of the year's average value of the New York Stock Exchange index, found to be significant by Joseph Minarik, for the insignificant proportional change in real GNP. ${ }^{18}$ This minor change in specification improves the equation's overall fit, as determined by the $\bar{R}^{2}$ and Durbin-Watson statistic, although it has no qualitatively important effects on the results concerning the effects of taxation. ${ }^{19}$

Before considering further the coefficient of the lagged tax rate, it is useful to review the predictions of theory. One would predict that an expected increase in next year's tax rate would increase current realizations, as investors speed up realizations. Indeed, one would expect the degree of uncertainty about such tax rates to matter, as well, since holding a capital gain is like buying an option based on future tax rates. Empirically, this additional refinement cannot be tested given the limited years of data available. The theoretical role of the lagged tax rate is a bit more difficult to ascertain. In a structural model of capital gains realizations, one might well argue that it is irrelevant. The lagged tax rate plays no clear role in an individual's current optimization problem trading off the gains of portfolio adjustments against the tax costs of realization. Nonetheless, there are two conceivable reasons for including the lagged tax rate if one interprets equations such as equation 4 as reduced forms.

First, one may justify inclusion of a lagged tax rate as a proxy for future tax rate changes, in much the way that traditional empirical tests of the permanent income hypothesis included lagged as well as current

18. Minarik, "The New Treasury Capital Gains Study."

19. Indeed, regressions reported in an earlier draft of this paper for the specification based on lagged GNP are even stronger in their support of the effects of anticipated tax changes than the results presented below. Using as an alternative to the NYSE index the midyear values of the Federal Reserve's wealth variable produced results almost identical to those reported, suggesting that long-term capital gains realizations respond to wealth changes with a short lag. This result makes sense, given that for most of the sample period the minimum holding period for long-term capital gains was six months.

Another variable considered in equations not reported was the value of noncorporate equity, which includes household real estate holdings. This variable was insignificant, and its inclusion had little effect on other coefficients. Likewise having little effect was the addition of more than one lagged value of the tax rate and using only capital gains rather than total changes in value (which also include new purchases) of corporate and noncorporate equity. 


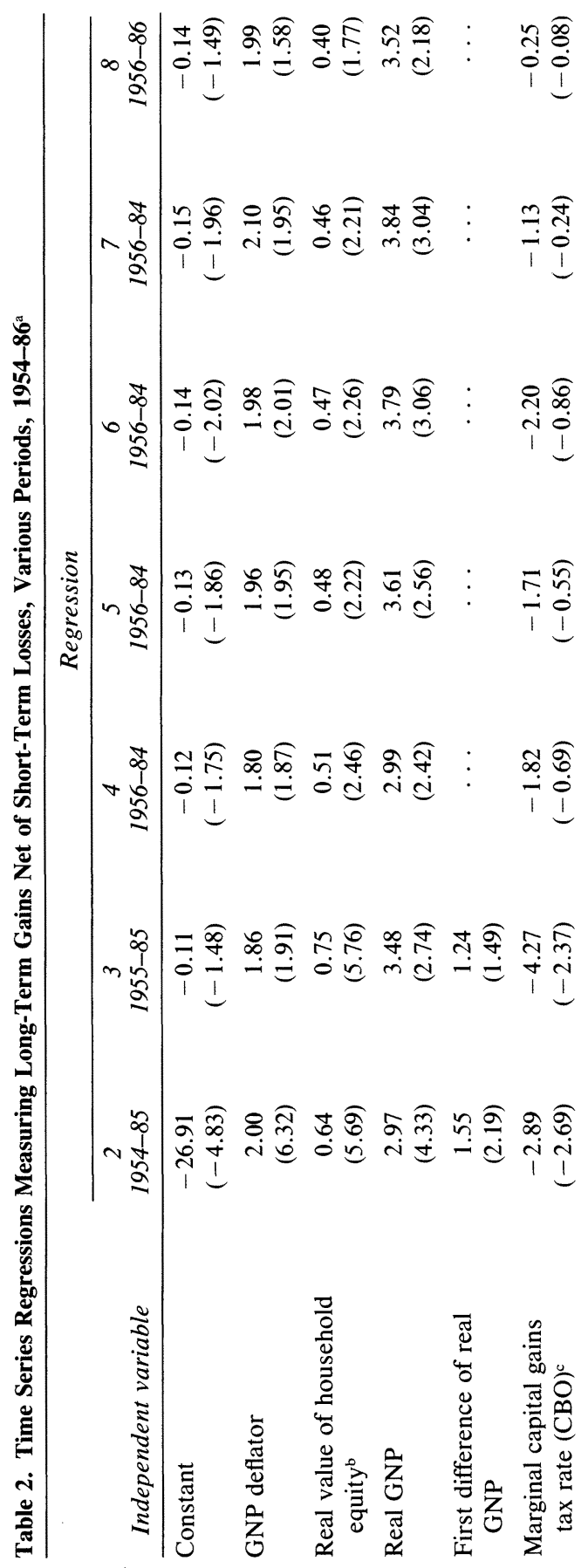




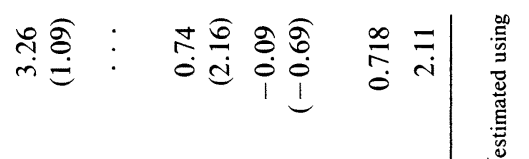

$$
\begin{aligned}
& \text { भิ⿵人一 }
\end{aligned}
$$

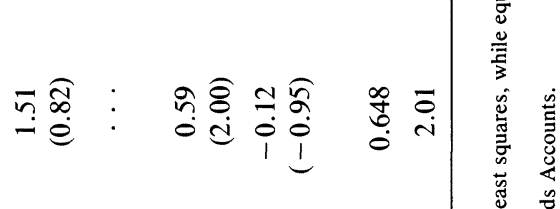

$$
\begin{aligned}
& \text { iv }
\end{aligned}
$$

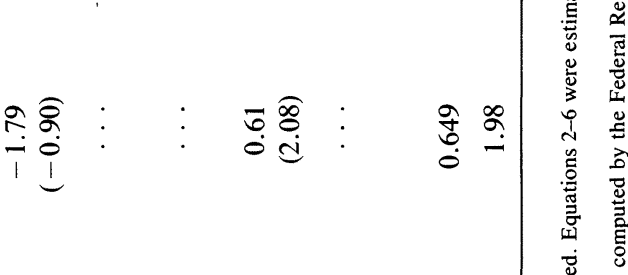

$$
\begin{aligned}
& \begin{array}{l}
\vdots \\
\vdots
\end{array} \quad \vdots \quad \vdots \quad \vdots \quad \text { ơ }
\end{aligned}
$$

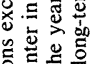

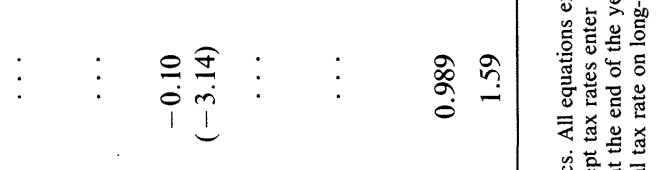

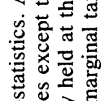

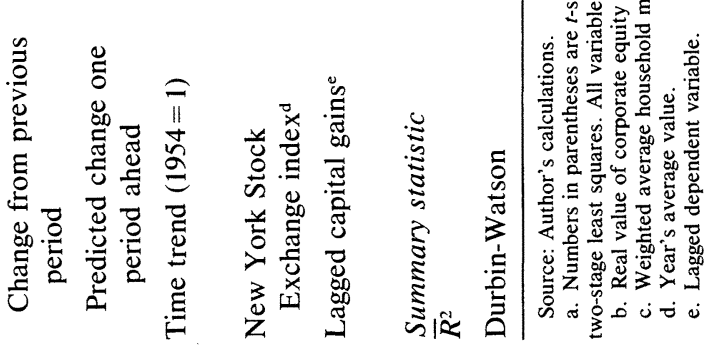


income as explanatory variables. One might expect the lagged tax rate to have a positive coefficient, as high past tax rates relative to the present indicate that tax rates may rise in the future. Here, as in other contexts, one faces the "Lucas critique" that in this reduced-form equation the coefficient of the lagged tax rate depends on two structural relationships, the responsiveness of realizations to expected future tax rates and the process relating future tax rates to current and lagged tax rates. Hence, the coefficient is difficult to use in predicting the effects of a policy change that changes not only the level of tax rates but also the environment in which tax rates are set.

A second reason for including the lagged tax rate is as a proxy for investors' past realization practices. Even a permanent change in tax rates would have different short-run and long-run effects because of the initial level of unrealized gains when the tax change occurs. For example, if taxes are lowered, investors might initially have very high levels of unrealized gains, having realized few gains during the preceding hightax years. During the first years after the tax cut, a transition to a generally higher rate of realizations out of total gains would cause realizations to rise more initially than in the long run. ${ }^{20}$ Thus, if taxes were high in the past, previous realizations might have been lower, leading to higher realizations today. Here, again, the lagged tax rate is serving as a proxy for another variable, in this case past realizations or the level of locked-in gains.

In both cases, one might expect the change in tax rates over the past year to have a negative sign. Though it does have this sign in equations 4 and 5 , it never enters with any significance. It is particularly insignificant in equation 5 when the one-period-ahead tax rate change and lagged capital gains also appear in the specification, supporting the argument that it does not belong in the equation. ${ }^{21}$

20. This point is made in more detail by Donald W. Kiefer, "The Capital Gains Response to a Tax Rate Change: Is It Overestimated?' Congressional Research Service Report (March 18, 1988), who demonstrates its importance using regressions based on simulated data.

21. A comparison of equation 4 and equation 6 , which replaces the current tax rate change with the future tax rate change and lagged capital gains, suggests that the overall fit is about the same, so that the statistical (as opposed to theoretical) superiority of the latter approach is questionable. However, once the sample period is extended through 1986 , the results diverge considerably. Compared with the $\bar{R}^{2}$ of 0.718 reported in equation 8 for the second specification, the use of the current change in taxes leads (in a regression not reported in the table) to an $\bar{R}^{2}$ of 0.563 . 
In equation 5, where both tax rate changes enter, the future tax rate change performs somewhat better than the change over the past year, but it is still insignificant, even when the tax change over the past year is dropped in equation 6 . For two reasons, it is, in principle, preferable to enter a fitted value of this variable in the regressions using instruments present in the information set at the current date. First, there may be simultaneous equations bias of uncertain direction if the current level of capital gains realizations affects future tax rate changes. Second, and probably more important, future tax rates are not always known in advance. Under the rational expectations hypothesis, actual future tax rates are distributed around the rate currently expected. Using the actual tax rate in the equation will thus bias the coefficient estimate toward zero by the standard errors-in-variables argument.

The coefficient of the future tax rate change in equation 7 , which is estimated using two-stage least squares, suggests indeed that such downward bias is present in the ordinary least squares estimates. ${ }^{22}$ The future tax rate's effect in equation 7 , though economically important, is estimated imprecisely, reflecting the difficulty of predicting future tax rates using aggregate time series variables.

Lagged capital gains enters with the "correct" sign in equations 5-8, suggesting that capital gains realized today are reduced by roughly one dollar for every ten dollars of capital gains realized a year earlier. As with the expected future tax rate change, these coefficients are economically significant but estimated with little precision.

\section{PERMANENT TAX EFFECTS}

Adding current or predicted tax rate changes to the specification drastically alters the estimates of the permanent effect of tax changes. In equation 7 , the permanent effect, equal to the coefficient of the current tax rate itself, is just -1.13 , with a $t$-statistic of just -0.24 , making the permanent effect considerably smaller and even less significant than the temporary one. When evaluated at the sample mean marginal tax rate, the implied permanent tax elasticity in equation 7 is -0.20 . The "temporary" elasticity, associated with the additional realizations that would attend a one-year tax change that is expected to be entirely reversed the

22. Excluded variables used as instruments are lagged values of all included exogenous variables, including the marginal tax rate. 
following year, equals the expected tax change coefficient times the sample mean tax rate, or -0.45 .

It should be stressed that the low $t$-statistics associated with the tax rate coefficients do not imply that taxes are unimportant in their impact on capital gains realizations. Indeed, largely because of the significant increase in capital gains taxes for 1987, equations in table 2 that include the future tax rate do predict a large increase in realizations for 1986, though not as large as the actual increase. For example, the level of 1986 realizations predicted using equation 7 and based on actual 1985 realizations is $\$ 265.1$ billion, below the actual value of $\$ 324.8$ billion but significantly above the $\$ 166.4$ billion of gains realized in $1985 . .^{23}$

Given these underpredictions, it is not surprising that including 1985 and 1986 in the estimation sample period increases the coefficient of the expected tax change term in equation 7 . The result is reported as equation 8 . In this equation, the permanent tax effect is just -0.25 , with a $t$-statistic of -0.08 . The evidence for a permanent tax effect is weak indeed.

What conclusions about existing time series evidence may one draw from these results? ${ }^{24}$ First, researchers have not paid adequate attention

23. Aggregate marginal tax rates for 1986 and 1987 that are exactly comparable to the CBO measures for 1954-85 are not available, and would require calculations based on microeconomic data similar to those performed by CBO. However, the CBO report does give such measures for 1988 based on 1988 (post-tax-reform) and 1986 (pre-tax-reform) tax laws. These should be similar to the unavailable 1986 and 1987 aggregate tax rates, and are used in their place.

24. The relatively similar data and approaches of most time series studies mean that these conclusions apply quite generally to past time series efforts. One possible exception is Lindsey, "Capital Gains: Rates, Realizations, and Revenues," who considered a pseudo-panel, a series of annual cross-sections made up of separate adjusted gross income classes reported in the annual IRS Statistics of Income: Individual Tax Returns. Lindsey found large coefficients for tax rates, with values for the current tax rate in the semilog level specification ranging from -5.1 to -7.4 . Attempts by CBO, How Capital Gains Tax Rates Affect Revenues, to estimate approximately the same equations on aggregate time series found the tax rate effects to be considerably smaller, even smaller than those reported in table 1. The CBO study attributes this to its lack of Lindsey's cross-section variation, a possibility given the very large responses found in some earlier cross-section work with microeconomic data (see below).

Another possible explanation may be Lindsey's use of cell aggregates (rather than these aggregates divided by the number of taxpayers in the cell) for variables such as capital gains and wealth. Given the large differences in cell size, this leads to a characterization of the lowest income cell as the wealthiest and the two highest income cells (where 
to the importance of the timing of tax changes. In equation 7 in table 2a specification that includes the predicted future tax rate change-the permanent effect is about one-third the size of the temporary effect of taxes on realizations. The permanent effect is virtually zero if 1985 and 1986 are added to the sample period (equation 8). Second, the tax rate coefficients are not estimated with enough precision to warrant strong conclusions about the impact of capital gains tax rates on realizations and revenue.

The extent of this uncertainty may be demonstrated by simulating the effects on revenues and realizations of a hypothetical tax cut under three plausible statistical assumptions. Consider a cut in the tax rate on longterm capital gains from 25 percent (the approximate value of CBO's weighted average marginal tax rate in 1988) to 15 percent, the rate recently proposed by President-elect Bush. For illustrative purposes, let us assume that average and marginal tax rates are equal, so that revenue effects can be easily computed, and that the tax change is known with certainty in advance. Each simulation is based on equation 8 . The first assumes that both the permanent tax effect and the tax change effect are zero. This leads to a "static" revenue loss calculation, since realizations are assumed not to change. The second simulation assumes the entire simulated tax effect to be permanent. If one reinterprets equation 8 as a regression on the current and future tax rates rather than current tax rate and future tax rate change, this amounts to assuming that the coefficient on the future tax rate is zero, and adding together the permanent and temporary effects of the current tax rate. Since the $t$ statistic of the future tax rate in this reinterpretation of equation 8 would be the same as that of the tax rate change in equation 8 , the assumption is surely plausible. The third simulation assumes that each coefficient equals its point estimate. None of these coefficient assumptions comes close to being statistically rejected.

Table 3 reports the results of these three simulations, beginning in the first year when revenues or realizations could change-that is, the year

a large fraction of the capital gains is concentrated) as the poorest. This surely leads to a biased estimate of the wealth elasticity of realizations, while the effect on the tax rate coefficient is difficult to guess. The (unavoidable) use of a standard income measure that includes realized capital gains to group taxpayers into cells may also have led to biased results. 
Table 3. Simulating the Effects on Revenues and Realizations of an Anticipated Reduction in the Marginal Tax Rate from 25 Percent to 15 Percent

Percent change

\begin{tabular}{|c|c|c|c|c|c|c|}
\hline \multirow[b]{2}{*}{$\begin{array}{l}\text { Year after } \\
\text { change }\end{array}$} & \multicolumn{3}{|c|}{$\begin{array}{c}\text { Realizations } \\
\text { Parameter assumptions }\end{array}$} & \multicolumn{3}{|c|}{$\begin{array}{c}\text { Revenues }^{\mathrm{a}} \\
\text { Parameter assumptions }\end{array}$} \\
\hline & Static $^{\mathrm{b}}$ & $\begin{array}{l}\text { No future } \\
\text { tax rate } \\
\text { effect }^{\mathrm{c}}\end{array}$ & $\begin{array}{l}\text { Point } \\
\text { esti- }^{\text {mates }}\end{array}$ & Static $^{\mathrm{b}}$ & $\begin{array}{l}\text { No future } \\
\text { tax rate } \\
\text { effect }^{\mathrm{c}}\end{array}$ & $\begin{array}{l}\text { Point } \\
\text { esti- }^{\mathrm{d}} \\
\text { mates }^{\mathrm{d}}\end{array}$ \\
\hline-1 & 0 & 0 & -28 & 0 & 0 & -28 \\
\hline 0 & 0 & 42 & 6 & -40 & -15 & -37 \\
\hline 1 & 0 & 38 & 2 & -40 & -17 & -39 \\
\hline 2 & 0 & 38 & 3 & -40 & -17 & -39 \\
\hline Long run & 0 & 38 & 3 & -40 & -17 & -38 \\
\hline
\end{tabular}

Source: Authors' calculations based on equation 8 in table 2.

a. Revenue calculations assume equal marginal and average tax rates.

b. Assumes that realizations are unaffected by tax rates.

c. $M T R(+1)$ in equation 8 implicit in the $D M T R(+1)$ variable set equal to zero.

d. Point estimates from equation 8 in table 2 .

before the tax rate changes, denoted year -1 . The static simulation shows no change in realizations and a 40 percent- $(25-15) / 25-$ decline in tax revenues in each year after the tax reduction. The second simulation yields revenue effects similar to those reported by the CBO. ${ }^{25}$ Realizations increase each year about 40 percent, and revenues, though falling, decline by less than half the static revenue loss. However, the third simulation, in which virtually all the tax effect is temporary, tells quite a different story. Once tax rates have changed (and are not expected to change again), realizations change scarcely at all after a small temporary increase in reaction to the drop in year -1 , and revenue declines by almost the 40 percent predicted by the static simulation. In addition, realizations and revenue fall 28 percent in the year before the tax change, as taxpayers await the decline in capital gains taxes. The net result of this third simulation is that revenues decline more, in present value, than in the first simulation, which assumes no response by investors to the tax cut.

The "bottom line" from the time series evidence is, therefore, that tax changes may exert a powerful effect on capital gains realizations, but the size of this effect and its revenue implications cannot be determined from such data alone.

25. CBO, "Simulating the Revenue Effects." 


\section{Further Evidence Based on Microeconomic Data}

The availability of tax return data at the level of individual households offers a promising alternative to aggregate time series data for research on the effects of capital gains taxes on realization behavior. The number of observations is typically a thousand times greater, and restrictive assumptions about the aggregability of individual responses into those of a "representative" household are unnecessary. Moreover, the information on households and assets of different types has permitted researchers to identify differences in behavioral responses among different classes of investors and with respect to the sales of different kinds of assets.

Of several studies using household data, some have found tax elasticities considerably larger than those from the time series studies. Martin Feldstein, Joel Slemrod, and Shlomo Yitzhaki produced one of the first studies using microeconomic data, based on a 1973 Treasury sample that included more detailed information on asset sales and capital gains than is normally retained by the Treasury in the drawing of its annual stratified sample for use in tax analysis. ${ }^{26}$ Looking exclusively at sales of corporate stock by individuals with at least $\$ 3,000$ in dividend income (and hence at least $\$ 100,000$ in common stock at the average dividend yield), they estimated the responsiveness of realized long-term gains and losses. Unlike the measures used in the time series studies, this measure includes positions with net long-term losses. ${ }^{27}$ As discussed below, the inclusion of such positions may have a strong influence on reported elasticities. Because some of their observations have negative dependent variables, Feldstein, Slemrod, and Yitzhaki could not use the semilogarithmic specification. Instead, they used a linear model to explain the ratio of gains (or losses) to adjusted gross income.

26. Martin Feldstein, Joel Slemrod, and Shlomo Yitzhaki, "The Effects of Taxation on the Selling of Corporate Stock and the Realization of Capital Gains, ' Quarterly Journal of Economics, vol. 94 (June 1980), pp. 777-91.

27. As discussed above, taxpayers with net long-term losses are likely to face constraints on the deductibility of such losses for tax purposes and hence a current marginal tax rate of zero. When analyzing microeconomic data, one can (and Feldstein, Slemrod, and Yitzhaki and other authors do) allow the taxpayer's marginal tax rate on capital gains to vary according to his situation. However, this cannot be done with aggregate time series, making such heterogeneity a problem. 
To avoid simultaneity bias, they treated actual marginal tax rates as endogenous, using two tax rates constructed to be independent of actual realization behavior as instruments. These constructed tax rates were, for each taxpayer, the first-dollar tax rate-the marginal tax rate faced on the first dollar of capital gains realized-and the predicted last-dollar tax rate-the marginal tax rate faced on the last dollar of capital gains that would be predicted on the basis of nontax characteristics.

Because of its linear form, the elasticity implied by the estimated equation is variable, but equals -3.75 for the regression based on their full sample when evaluated at reported sample means. A permanent elasticity this high would imply that a capital gains tax cut would raise tax revenue substantially, although the authors acknowledged that part of their measured effect may be temporary.

Joseph Minarik challenged these results on two grounds. ${ }^{28}$ First, he suggested using an average tax rate for predicted gains rather than the first-dollar and predicted last-dollar marginal tax rates used by Feldstein, Slemrod, and Yitzhaki, arguing that this is a better measure of the tax rate faced by investors deciding whether or not to realize gains. Although this criticism highlights the difficulty of representing a tax schedule by a single tax rate, there is no strong theoretical justification for choosing one summary tax rate over another. Without a model based on optimizing household behavior, it is hard to know exactly how the tax schedule should appear in the estimated regression.

Another potential problem in the measurement of marginal tax rates is that, with all individuals in a cross-section sample facing the same tax schedule, it is difficult to identify many truly exogenous sources of variation in marginal tax rates among taxpayers. Much of the variation observed in individual tax rates, even controlling for realized gains, may be due to behavioral differences, and this could lead to spurious results. ${ }^{29}$ For example, suppose individuals differ with respect to their taste for risk taking. Some hold safe and typically high-yield investments, while

28. Joseph Minarik, "The Effects of Taxation on the Selling of Corporate Stock and the Realization of Capital Gains: Comment," Quarterly Journal of Economics, vol. 99 (February 1984), pp. 93-110. Also see Minarik, "Capital Gains," in Henry J. Aaron and Joseph A. Pechman, eds., How Taxes Affect Economic Behavior (Brookings, 1981), pp. 241-77.

29. This argument is found in Gravelle, "Will Reducing Capital Gains Taxes Raise Revenue?" 
others hold riskier assets with little current taxable income but substantial growth potential. The latter group would have less measured income and a lower marginal tax rate than the former, but would on average accrue and presumably realize more capital gains. Given that gains for individuals with similar preferences would rise with income and wealth, this additional source of variation would bias downward the estimated effect of true income and overstate the impact of tax rates: one would observe too many relatively "poor" people with low marginal tax rates realizing gains.

Similar criticisms arise in other contexts, but it is difficult to know how serious a problem this is. The challenge is to identify an independent source of marginal tax rate variation to find out. One possibility is stateby-state variations in tax rules, which have been used for a similar sample to validate previous results in the area of charitable contributions. ${ }^{30}$

Minarik's second criticism of Feldstein, Slemrod, and Yitzhaki was that their use of unweighted ordinary least squares ignored the fact that the sampling technique, which stratified by adjusted gross income including realized capital gains, oversampled individuals who realized large gains. Using population-weighted least squares (with each observation weighted by the inverse of its sampling probability), he found a significantly smaller tax rate coefficient, corresponding at sample means to -0.44 in his preferred specification.

However, in their response, Feldstein, Slemrod, and Yitzhaki point out that if responsiveness to tax rates varies by sample weight (which in this stratified high-income sample is inversely related to income), reweighting will also shift the estimated effect toward that of the highweight (low-income) group. ${ }^{31}$ They confirm this effect, showing that the omission of relatively lower-income (adjusted gross income first below $\$ 50,000$, then below $\$ 100,000$ ) households before weighting brings the tax rate coefficient close to the value they estimated originally. That these omitted classes represent a relatively small fraction of capital gains realizations suggests that the relevant elasticity, if one is interested in

30. Daniel Feenberg, "Are Tax Price Models Really Identified: The Case of Charitable Giving," National Tax Journal, vol. 40 (December 1987), pp. 629-33.

31. Martin Feldstein, Joel Slemrod, and Shlomo Yitzhaki, "The Effects of Taxation on the Selling of Corporate Stock and the Realization of Capital Gains: Reply, " Quarterly Journal of Economics, vol. 99 (February 1984), pp. 111-20. 
aggregate predictions of realizations and revenue effects, is large after all.

Put another way, a cell's economic size rather than its population should be used in deriving its weight. ${ }^{32}$ The appendix demonstrates this result more formally. However, the appropriate choice of weighting scheme does not fully dispose of the problem of individual heterogeneity. Though it may ensure that aggregate revenue predictions are accurate, it will not correct the mistaken characterization of individual behavior imposed by the model. That mistake can be corrected only by allowing variations in tax-rate responsiveness among individuals according to their observable characteristics, a feasible improvement given the large number of cross-section observations.

A further problem of analysis based on a single cross section is that it is difficult to distinguish the temporary and permanent effects of taxation on realizations. Only one tax rate per taxpayer is observed, so the only way to estimate its relationship to the taxpayer's rate in other years (past or future) is by comparing it with the tax rates faced in the same sample and year by otherwise similar taxpayers. This further begs the question of identification raised above, and in any event will uncover variations in individual tax rates arising from idiosyncratic but not common factors, such as changes in tax legislation. A satisfactory solution requires the use of panel data.

Few studies to date are based on panels of microeconomic data. Gerald Auten and Charles Clotfelter examined a seven-year panel of taxpayers from 1967 through $1973 .{ }^{33}$ A cost of using such panel data is that information on detailed asset transactions is not publicly available, so that Auten and Clotfelter could not look separately at common stock transactions. In addition, their seven-year panel did not have the same degree of oversampling as did Feldstein, Slemrod, and Yitzhaki's 1973

32. Indeed, weights based on predicted capital gains were used by $\mathrm{CBO}$, How Capital Gains Tax Rates Affect Revenues, to calculate aggregate marginal tax rates for its time series regressions. The CBO's time series study also considers the relative responsiveness of low-income and high-income individuals, finding that the tax coefficients in the semilog specification for the top 1 percent and bottom 99 percent of tax returns are virtually identical. It is difficult to identify the source of the discrepancy between this result and the strong distributional effect identified by Feldstein, Slemrod, and Yitzhaki.

33. Gerald Auten and Charles Clotfelter, "Permanent versus Transitory Tax Effects and the Realization of Capital Gains, " Quarterly Journal of Economics, vol. 97 (November 1982), pp. 613-32. 
data on the high-income individuals who realize such a substantial portion of all capital gains. Given the apparently different behavior of high- and low-income taxpayers, this is a potentially important consideration. Only about one-third of their sample realized gains.

To evaluate the impact of changes in tax rates on behavior, Auten and Clotfelter denote a three-year moving average of a taxpayer's tax rate as the permanent tax rate and the difference between that and the current marginal tax rate as the temporary tax rate, using a first-dollar tax rate measure. As discussed above, it is difficult to interpret the coefficients of lagged tax rates because they proxy for the effects of expected future tax rates and past realization behavior. Nevertheless, their inclusion is a significant step forward.

In the semilog specification explaining long-term gains net of shortterm losses, the same functional form and dependent variable used in the time series analysis presented above, Auten and Clotfelter find a statistically insignificant realization elasticity of -0.36 with respect to the permanent tax rate and a statistically significant elasticity of -0.91 with respect to the temporary tax rate. Though these elasticities are qualitatively similar to those reported for the time series regressions above, one must keep in mind that the temporary tax effect has a different interpretation here, being associated with the change from a taxpayer's moving average tax rate rather than the change from an anticipated one. ${ }^{34}$

When, following Feldstein, Slemrod, and Yitzhaki, Auten and Clotfelter include observations with net long-term losses and use a linear rather than semilogarithmic specification, they find much higher elasticities, -1.45 with respect to permanent tax changes and -3.46 with respect to temporary tax changes, both significant. Added together, these actually exceed Feldstein, Slemrod, and Yitzhaki's estimated

34. One must also recognize that if the true household model is semilogarithmic, then the tax rate coefficient derived from an aggregate time series regression based on the same semilogarithmic specification need not yield precisely the true behavioral coefficient unless the cross-section distribution of tax rates remains stable over time even as the mean tax rate fluctuates. Likewise, the use of such an aggregate coefficient to simulate the behavior of individual households need not yield the same total effect as a simulation based directly on aggregate data. The use of this microeconomic simulation procedure by $\mathrm{CBO}, \mathrm{How}$ Capital Gains Tax Rates Affect Revenues, has been criticized by Darby, Gillingham, and Greenlees, "Direct Revenue Effects," but CBO, "Simulating the Revenue Effects," finds the resulting error to be minor. 
overall tax elasticity, suggesting, somewhat to one's surprise, that sample differences and the inclusion of capital gains on assets other than common stock may not have a significant effect on the results.

It is important to clarify why these two sets of results (excluding and including observations with net losses) differ so much. In general, including observations with losses is likely to increase estimated elasticities. The crucial issue is which elasticity is most relevant for predicting aggregate changes in tax revenue. The large elasticities based on samples that include losses are likely to overestimate aggregate revenue effects.

To understand why estimated elasticities are likely to rise when losses are included, consider the following simplified model. Individuals are of two types, those with net gains and those with net losses. Realization of gains is governed by the expression:

$$
G=-a t_{+}+c,
$$

and realization of losses by the expression:

$$
L=b t_{-}+d,
$$

where $t_{+}$is the tax rate on gains, $t_{-}$is the tax rate on losses, $c$ and $d$ are constants, and one would expect the coefficients $a$ and $b$ to be positive.

The elasticity of realizations of gains by the entire population, evaluated at the sample mean $\bar{G}$, is $e_{+}=-$wat $_{+} / \bar{G}$, where $w$ is the fraction of the population having gains. Including losses, one obtains an elasticity of $e=-\left[w a t_{+}+(1-w) b t_{-}\right] /(\bar{G}-\bar{L})$, where $\bar{G}-\bar{L}$ is the average net gain. It is clear that $e$ must exceed $e_{+}$in absolute value, since the average gain exceeds the average gain less loss, and $(1-w)$, $b$, and $t_{-}$are all nonnegative. This result holds even if the responsiveness of those with losses to taxation, $b$, equals zero. For those with losses, the elasticity of realizations with respect to taxes is so high as to be undefined when the base level of realizations is negative. Including such individuals in the sample increases, in absolute value, the estimated aggregate elasticity.

Each of these elasticity calculations is correct in describing the sample on which it is based. However, if one wishes to use the elasticity for a prediction of aggregate revenue effects, then including individuals with losses, many of whom face a zero marginal tax rate, is inappropriate. In this example, if $t_{-}=0$, then the elasticity $e_{+}$yields an accurate estimate of the revenue effects of tax changes; the high elasticity of individuals 
with losses is irrelevant because these individuals' realizations have no impact on revenue. More generally, as shown in the appendix, the appropriate aggregate elasticity for revenue calculations equals the average of individual elasticities weighted by individual capital gains tax payments. If individuals with losses face lower than average capital gains tax rates, the elasticity based on the full sample will overstate the responsiveness of tax revenue.

Thus, Auten and Clotfelter's results provide a bridge between the very low permanent tax rate elasticity found using time series and the very high tax rate elasticity found by Feldstein, Slemrod, and Yitzhaki. First, Auten and Clotfelter attribute about two-thirds of the overall tax effect to timing. Second, they show that looking at long-term gains net of losses rather than just long-term gains more than triples the size of both permanent and temporary elasticities. However, these large elasticities overstate the ability of capital gains tax cuts to raise revenue.

Somewhat at odds with Auten and Clotfelter's results are those reported by the Treasury. ${ }^{35}$ Based on a (not publicly available) stratified high-income sample with asset detail like Feldstein, Slemrod, and Yitzhaki but unlike Auten and Clotfelter, it covers realizations during 1973-75. For the semilog specification based on realizations of long-term gains, it reports a permanent tax elasticity of -1.29 for all gains and -2.07 for corporate shares.

There are several possible sources of the discrepancy between these results and those Auten and Clotfelter report, although their relative importance is difficult to gauge. One is sample differences, in both sample period and sampling method. A second is differences in specification: the Treasury study includes the square root as well as the level of the permanent tax rate in its specification. A third difference may come from the way the elasticities are calculated. While Auten and Clotfelter report a point-of-means elasticity, the Treasury study reports an elasticity based on the aggregate simulation results, essentially an average of individual elasticities weighted by their realized capital gains. As shown in the appendix, what one would actually like for revenue calculations is an elasticity weighted by individual capital gains tax payments, although Treasury's simulated revenue gain from the 1978 tax cut 
suggests that this appropriate elasticity is also greater than 1 in absolute value.

As noted, a problem inherent in cross-section data is an investigator's inability to distinguish temporary and permanent tax rate effects for any individual, as well as to control for persistent individual differences in both realized capital gains and tax rates that could be attributable to other factors. The first of these problems has been dealt with in panel studies. The latter problem could also be attacked using panel data through an explicit allowance for individual heterogeneity, as in a model with fixed effects, although this would make it harder to identify separately the effects of differences in permanent tax rates. The basic problem even with panel data is that one principal exogenous source of variation in tax rates is the common one due to changes in the tax law.

Aside from other issues already covered, a problem common to all the previous literature is its failure to incorporate the dynamic aspects of the capital gains tax rules. In particular, the current marginal tax rate on capital gains has been treated as the effective rate on such gains. In reality, a taxpayer facing a current marginal tax rate of zero because of excess losses faces a higher marginal tax rate overall, once future changes are taken into account. An increase in gains realized by an investor with excess current losses will reduce that investor's capital loss carryover, increasing the expected future capital gains tax liability. One can construct a "shadow" tax rate based on this increase, whose value may be very close to a taxable investor's tax rate if the loss carryover is expected to be used up in the near future. It is this tax rate, which may be estimated using panel data, that is relevant for realization decisions for taxpayers facing no current marginal tax liability. ${ }^{36}$

In conclusion, the cross-section evidence is less at variance with the time series evidence than has been generally thought. Larger crosssection elasticities can be explained in part by differences in dependent

36. For a discussion of the shadow value approach in the context of tax loss carryforwards, see Alan J. Auerbach, "Corporate Taxation in the United States," BPEA, 2:1983, pp. 451-505. This issue may be quantitatively important, since many taxpayers do face constraints. Minarik, "The Effects of Taxation on the Selling of Corporate Stock and the Realization of Capital Gains: Comment," reports that 29.0 percent of taxpayers in his 1973 sample with dividends in excess of $\$ 50,000$ had zero first-dollar tax rates, and 23.4 percent had zero last-dollar tax rates. Poterba, "How Burdensome Are Capital Gains Taxes?" reports that 18.1 percent of his 1982 sample (weighted by dividends) faced a zero last-dollar marginal tax rate. 
variables and in the treatment of temporary tax changes. However, even after making these corrections, at least one panel study does find greater than unitary tax realization elasticities for gains on common stock and all long-term gains. The implications for revenue estimation are unclear. Beyond the difficulty of reconciling the variety of available estimates is the problem already raised that observed variations in permanent tax rates in these samples capture individual differences rather than differences in tax policy over time. The assumption that these individual tax rate differences are not simultaneously influenced by differences in capital gains realization behavior has not been adequately tested. With greater attention paid to this and the several other problems raised in this section, future work with panel data could be quite valuable.

\section{Tax Arbitrage and Its Implications}

Most policy discussions of capital gains tax cuts seem to be based on the premise that increases in realizations would result from increased asset turnover and fewer capital gains being held until death. One should certainly also mention increased compliance, given recent evidence that the fraction of realizations reported is inversely related to the capital gains tax rate. ${ }^{37}$

Such analysis takes a familiar approach to studying the effect of taxation: it assumes that there is a taxed and an untaxed activity and that reductions in the rate of tax cause a shift toward the taxed activity. Basic textbook analysis of the incidence and efficiency effects of taxation follows the same paradigm. Among its implications are that a large response of the taxed activity to the tax rate shows that the tax is distortionary and that the revenue effects of a change in the tax rate may be measured by looking only at the direct revenues from the taxed activity.

Yet because much of capital gains realization activity represents " tax arbitrage," with taxpayers realizing long-term capital gains and paying taxes to avoid other, higher taxes, a different analytical approach to questions of efficiency and incidence is needed. A tax cut that increases

37. See James M. Poterba, "Tax Evasion and Capital Gains Taxation," American Economic Review, vol. 77 (May 1987), pp. 234-39. 
realizations through increased arbitrage actually may reduce efficiency, because it lowers tax revenue and forces increases in other distortionary taxes. Likewise, the total taxes paid by those who increase their arbitrage activities actually decline. Thus, a policy that lowers the capital gains tax rate but increases the capital gains taxes paid by certain individuals may actually represent a shift of the direct overall tax burden to others.

As many authors have pointed out, capital gains realizations may be especially sensitive to taxation because they are financial transactions that need not be closely connected to changes in real behavior. There is solid evidence that investors follow end-of-year loss realization strategies and hold gains until they qualify for long-term tax treatment. ${ }^{38}$ Such behavior may be thought of as passive tax arbitrage, possible even if investors' portfolios are themselves not influenced by the existence of capital gains taxes. Corresponding to tax revenues collected from realizations of long-term gains are greater revenues lost on realized short-term losses.

However, active manipulation of portfolios through a series of hedging transactions that create offsetting gain and loss positions, combined with the ability to hold gains and realize losses, allows an investor, at least in theory, to approach pure arbitrage strategies, in which underlying portfolio disruptions caused by the offsetting transactions are minimal, and arbitrarily large tax reductions may be generated. ${ }^{39}$

In the presence of this kind of arbitrage, reductions in the realization of certain long-term gains may very well signify a net increase in tax revenue and an increase in economic efficiency as well, as the social resources expended engaging in arbitrage are also reduced. Consider, for example, the capital gains tax changes of 1986. On the one hand, the increased tax on long-term realizations reduced the incentive to realize locked-in long-term capital gains, a clear increase in the distortion of individual economic behavior. On the other hand, by removing the

38. Joel Slemrod, "The Effect of Capital Gains Taxation on Year-End Stock Market Behavior," National Tax Journal, vol. 35 (March 1982), pp. 69-78; Thomas A. Barthold, "Investor Capital Gains Realization Behavior in Response to Capital Gains Tax Rates", (Dartmouth College, n.d.); Stephen Kaplan, "The Holding Period Distinction of the Capital Gains Tax," Working Paper 762 (National Bureau of Economic Research, September 1981).

39. George M. Constantinides, "Capital Market Equilibrium with Personal Tax," Econometrica, vol. 51 (May 1983), pp. 611- $\rightarrow$ Joseph E. Stiglitz, "Some Aspects of the Taxation of Capital Gains," Journal of Public Economics, vol. 21 (July 1983), pp. 257-94. 
distinction between realized long-term capital gains and other income, the 1986 act also may have reduced long-term realizations by lowering the incentive to engage in socially wasteful transactions to generate long-term gains and short-term losses and in other ways convert fully taxable income into capital gains.

To weigh these two effects, it is important to know how significant tax arbitrage is in the realization of capital gains. Even though aggregate realizations year-in and year-out are dominated by long-term gains and short-term losses, the kind of matching one would expect from arbitrage trading does not appear.

In 1982, for example, $\$ 95.7$ billion of gross long-term capital gains was reported on individual tax returns..$^{40}$ Long-term losses and loss carryovers offset $\$ 7.3$ billion of this amount, and short-term losses another $\$ 2.3$ billion, leaving long-term gains net of short-term losses of $\$ 86.1$ billion. At the same time, gross long-term losses and loss carryovers amounted to $\$ 21.0$ billion. As noted, $\$ 7.3$ billion of this amount offset long-term gains, another $\$ 1.1$ billion offset short-term gains, and $\$ 2.6$ billion was used to offset other income. The remaining $\$ 10.0$ billion was carried forward as long-term loss carryovers. Thus, most long-term gains were not matched by losses, and nearly half the long-term losses provided no reduction in current taxes. A similar story holds for shortterm gains and losses. Of $\$ 18.9$ billion of gross short-term losses and short-term loss carryovers, only $\$ 6.3$ billion went to offset capital gains and $\$ 3.5$ billion to offset other income. Individual taxpayers entered 1982 with carryovers of $\$ 8.1$ billion of long-term losses and $\$ 8.0$ billion of short-term losses, and carried $\$ 10.0$ billion and $\$ 9.1$ billion, respectively, into $1983 .{ }^{41}$

While pure arbitrage based on capital gains and losses may not be the primary activity generating capital gains realizations, other potential sources of increased realizations also result from tax arbitrage. Already discussed above was the timing effect, with individuals transferring gains from high-tax to low-tax years.

In addition, lower capital gains taxes may cause investors to shift

40. The following calculation relies on data provided by Poterba, "How Burdensome Are Capital Gains Taxes?" table 2; and Internal Revenue Service, Statistics of Income: Individual Tax Returns, 1982 and 1983.

41. Further discussion of the empirical evidence relating to arbitrage behavior may be found in Poterba, "How Burdensome Are Capital Gains Taxes?" 
from more fully taxed assets, increasing portfolio distortions and again reducing tax revenue. There is some evidence of this behavior in aggregate data, but it has not been evaluated using microeconomic data. ${ }^{42}$ Finally, capital gains taxes often change when other taxes change. Ignoring such changes in time series analysis may, in some cases, overstate the impact of the capital gains tax cut on realizations and revenue. For example, in 1981, the Economic Recovery Tax Act not only cut capital gains taxes but also introduced the Accelerated Cost Recovery System, encouraging investors to sell depreciable property being written off under less favorable rules. Such realizations would not have been caused by the capital gains tax cut alone and would have reduced tax revenue from these assets in subsequent years. That data on capital gains realizations by asset type are not available on an annual basis makes it difficult to evaluate the importance of this effect.

One must also consider the implications of tax arbitrage behavior with respect to the specification and choice of the dependent variable in behavioral models. There are really several behavioral decisions at work determining each taxpayer's level of gross long-term gains, gross longterm losses, gross short-term gains, and gross short-term losses. Theoretical justification is weak for imposing the restrictions implicit in the estimation of a single equation for long-term gains net of short-term losses, which aggregates the four categories. Equal changes in this aggregate due to changes in different components may have different implications, and offsetting changes in components that have no impact on the aggregate may represent important behavioral changes. For example, an anti-arbitrage policy that reduces gross gains and losses equally and has no effect on net gains could increase economic efficiency.

As this consideration of tax arbitrage indicates, special caution is demanded in applying standard welfare analysis to the existing empirical estimates of the effects of capital gains taxation. Subsequent empirical investigations must take more seriously the implications of tax arbitrage, starting with the most basic allowance for future tax changes and the tax treatment of other assets and then attempting to distinguish the different motives for realizing capital gains. This is not a simple task.

42. Eric W. Cook and John F. O'Hare, "Issues Relating to the Taxation of Capital Gains," National Tax Journal, vol. 40 (September 1987), pp. 473-88, find that interest and dividend income is negatively and significantly related to the spread between the maximum tax rates on ordinary income and long-term capital gains. 


\section{The Goals of Capital Gains Tax Reductions}

So much attention has been given to the revenue effects of capital gains tax cuts that their underlying objectives have received little scrutiny. It is safe to say that the encouragement of tax arbitrage is not explicitly such an objective, even though it may be a side effect. More reasonable objectives include the reduction of the lock-in effect on holding gains, relief from tax of the inflation-induced component of capital gains, and encouragement of risky enterprises. A brief review of these objectives shows that cutting capital gains taxes is not the best way to achieve them.

Reducing or eliminating capital gains taxes would surely reduce the lock-in effect, but so would other policies. The simplest one would be to replace the current step-up in basis at death with the taxation of capital gains through constructive realization or with the less potent policy of basis carryover. ${ }^{43}$ Both policies would reduce the lock-in effect by increasing future taxes instead of decreasing current ones. Comparing them with capital gains tax reductions amounts to asking whether it is better to achieve more uniform taxation by raising the low tax rates or lowering the high ones. Since the two types of policy differ primarily with respect to the general level of tax imposed on assets yielding capital gains, the answer depends on what that level of tax should be. While this question may be difficult to answer, a clearer path toward increased efficiency would be to follow a policy that maintained the present lifetime tax burden on capital assets by increasing taxes at death and reducing the current rate on realized gains, reducing the lock-in effect without changing the overall investment incentive. To the extent that estates arise from precautionary saving rather than a bequest motive, this policy would be even more attractive, since such saving would not be influenced by an increased tax burden after death.

43. Basis carryover was scheduled for introduction by the Tax Reform Act of 1976, but was repealed before taking effect. Auten and Clotfelter's results provide evidence that as taxpayers age, their capital gains realizations rise and then, after age 75, fall. This is consistent with the theory that (because assets have positive expected returns) accrued gains increase with age but that as the time of bequest approaches, the tax incentive to hold gains becomes increasingly strong. 
That capital gains taxes tend to be cut during periods of high inflation (such as 1978 and 1981) is more than coincidence. As has been well documented, realized capital gains may be subject to tax rates that easily exceed 100 percent of real gains in the presence of inflation..$^{44}$ Reducing the rate of tax on nominal realized gains ameliorates this effect, but indexing of capital gains for inflation does so in a more direct and accurate manner. ${ }^{45}$

In an efficient capital market, there is no argument a priori for encouraging risk taking. When capital gains are taxed on realization, arguments appear. Unlike other asymmetries in the tax code regarding the treatment of losses, the limitation on capital losses is quite rational and necessary because of the voluntary nature of realizations. Without it, investors with large portfolios could eliminate their entire tax obligations with little difficulty. Caught in this net of second-best treatment, however, are investors in risky assets, since assets with a high degree of undiversifiable risk are more likely than relatively safe assets to land an investor in a situation in which he has aggregate losses well in excess of accrued gains yet may not deduct them. ${ }^{46}$

Indexation alone offers little help when the marginal tax rate is often zero; taxpayers with losses in excess of the $\$ 3,000$ limitation receive no current tax reduction from a policy that simply increases the size of the losses they cannot deduct. Hence, indexing would further widen the gap in tax treatment between risky and safe investments. Therefore, if the problem of losses cannot be attacked directly, a reduction in rates may seem attractive as a solution to help risky enterprises.

However, even though the new high-technology firms often seen as the prototype of risky venture-capital investments do rely heavily on the sale of new equity, a recent calculation by the Treasury estimated that about 0.1 percent of outstanding corporate equity is associated with

44. See Martin Feldstein and Joel Slemrod, "Inflation and the Excess Taxation of Capital Gains on Corporate Stock," National Tax Journal, vol. 31 (June 1978), pp. 107-18.

45. A plan to combine the increased taxation of long-term capital gains with indexation was put forward in the U.S. Department of the Treasury, Office of the Secretary, Tax Reform for Fairness, Simplicity and Economic Growth (Treasury, 1984), but only the first part of the plan was ultimately followed.

46. The effect of capital loss limitations on risky investment has long been recognized. See, for example, Joseph E. Stiglitz, "The Effects of Income, Wealth, and Capital Gains Taxation on Risk-Taking," Quarterly Journal of Economics, vol. 83 (May 1969), pp. 263-83. 
venture capital operations. ${ }^{47}$ Cutting all capital gains taxes seems far too broad a measure to help such firms.

A direct and fundamental solution to the lock-in effect and the problem of loss limitations would be to tax capital gains on accrual rather than realization. As in the example above of shifting to heavier taxation at death, one could construct an accrual tax that would, on average, not impose a heavier burden on overall capital gains while at the same time eliminating the lock-in effect and permitting a full deduction of accrued capital losses. A compelling case could be made that such a shift would lead to significant efficiency gains.

Accrual taxation has already been adopted for some financial instruments through so-called "mark-to-market" rules, and could easily be applied in cases of publicly traded common equity, on which most of the capital gains discussion has centered. The problems associated with accrual taxation apply primarily to other assets, for which market values may not be known, and taxpayers may lack the liquidity to pay taxes on an asset's accrued gains and be unable to sell only part of the asset to do so. Even in such cases, the problems may be overstated and alternatives similar to accrual taxation exist. ${ }^{48}$ It is puzzling why this family of alternatives receives so little attention, even from economists.

\section{Conclusions}

Capital gains taxes have a strong impact on the way investors time the realization of their long-term capital gains. That fact, however, implies little about the costs and benefits of reducing capital gains tax

47. Treasury, Capital Gains Tax Reductions of 1978, p. 139. The study goes on to point out that roughly half the equity in such companies was provided by pension funds and other investors not affected by changes in capital gains tax rates.

48. David J. Shakow, "Taxation without Realization: A Proposal for Accrual Taxation," University of Pennsylvania Law Review, vol. 134 (June 1986), pp. 1111-1205, estimates that relatively few taxpayers would lack the liquidity to pay taxes on accrued gains, even without shifting their portfolios. Liquidity problems could also be addressed by allowing taxpayers to accumulate their tax liabilities until gains were realized, following the cumulative averaging scheme first described by William Vickrey, "Averaging of Income for Tax Purposes," Journal of Political Economy, vol. 47 (June 1939), pp. 37997. Even the unobservability of market values before realization can be overcome by imposing a retrospective tax on realizations that has the same incentives during the holding period as accrual taxation. See Alan J. Auerbach, "Retrospective Capital Gains Taxation" (University of Pennsylvania, April 1988). 
rates. Before policymakers take such a step, they should know far more than anyone yet knows about the permanent impact of taxes on capital gains realizations and about what changes in realizations signify.

Future empirical analysis with panel data should aim at a more exact decomposition of tax effects into temporary and permanent components, a better modeling of the dynamic aspects of realization behavior (including the proper measurement of the marginal tax rates facing constrained taxpayers), a more satisfactory treatment of investor heterogeneity, and more careful attention to the presence of tax arbitrage. Policymakers need to recognize not only the empirical uncertainties about the effects of capital gains taxes, but also the full range of available alternatives.

\section{APPENDIX}

IN USING cross-section data to calculate the appropriate elasticity of realizations with respect to tax rates, one must deal with two separate issues relating to the weighting of observations. First, for a given model specification, the true response to tax rates may differ among members of the sample. Hence, the single coefficient estimated will be a weighted average of the true underlying responses, with the weights depending on the weight given each observation in the estimation process. How should these estimation weights be chosen? Second, even if each individual's underlying response to taxation is estimated consistently, the elasticity of realizations with respect to tax rate changes will generally vary across individuals, unless each has the same measured response and a constantelasticity (that is, log-log) specification applies. In a single semilog specification, for example, individuals with different levels of capital gains realizations will have different elasticities with respect to tax rates. How should these different elasticities be weighted to obtain a single aggregate elasticity?

One may be tempted simply to apply population weights in each case, to arrive at coefficients and elasticities that are representative of the population. But what does "representative" mean in this situation? If, as is the case, a large fraction of the population realizes a very small fraction of aggregate capital gains, the behavior of this group will have a small impact on aggregate capital gains realizations and on revenue. 
Why should they be given substantial weight in estimating coefficients or elasticities? Intuition suggests that weights should bear some relationship to capital gains realizations, or at least potential realizations, and this outcome can indeed be formally demonstrated. The key step is to specify the uses for which the coefficients and elasticities are intended, so that an explicit objective can be identified.

Consider first the estimation problem. Most analysts wish to estimate the responsiveness of capital gains realizations to tax rates so that they can then perform microeconomic simulations calculating the change in tax revenue with respect to a change in tax policy. What estimation weights will yield a tax rate coefficient that delivers unbiased estimates of the aggregate revenue response to tax changes? The answer depends on the type of tax rate change envisioned and the functional form of the estimated model, but the general intuition can be developed using an equiproportional tax rate change and the ratio (of gains to income) specification common to the cross-section literature.

The response of total tax revenue, say $R$, with respect to such a uniform change is

$$
d R=\sum t_{i} G_{i}\left(e_{i}+1\right),
$$

where $G_{i}, t_{i}$, and $e_{i}$ are, respectively, the realizations, tax rate, and elasticity of response of individual $i$ with respect to his tax rate. In the ratio specification, individual $i$ 's elasticity is

$$
e_{i}=b_{i} t_{i} Y_{i} / G_{i},
$$

where $Y_{i}$ is his income and $b_{i}$ his tax rate responsiveness. Substituting equation A.2 into equation A.1 yields the true response of revenue to the tax change:

$$
d R=\sum b_{i} t_{i}^{2} Y_{i}+\sum t_{i} G_{i}
$$

If $b^{*}$ is the aggregate estimate of the capital gains response, the estimated aggregate revenue effect will be

$$
d R^{*}=\sum b^{*} t_{i}^{2} Y_{i}+\sum t_{i} G_{i}
$$

Let $w_{i}$ be the weight that observation $i$ receives in the estimation procedure. We wish to choose the values of $w_{i}$ so that the expected value of $d R^{*}$ equals $d R$. In general, this is a difficult problem involving the 
calculation of aggregation bias. But, to gain intuition, consider the case of simple regression, where the expected value of $G_{i} / Y_{i}$ is $b_{i} t_{i}$. In this case the expression for $b^{*}$ from the regression of $G_{i} / Y_{i}$ on $t_{i}$ is

$$
b^{*}=\left(\sum w_{i} t_{i} G_{i} / Y_{i}\right) /\left(\sum w_{i} t_{i}^{2}\right) .
$$

Substituting equation A.5 into equation A.4 and taking its expectation, one obtains:

$$
E\left(d R^{*}\right)=\left(\sum w_{i} t_{i}^{2} b_{i}\right) /\left(\sum w_{i} t_{i}^{2}\right) \cdot \sum t_{i}^{2} Y_{i}+\sum t_{i} G_{i} .
$$

A comparison of equations A.6 and A.3 shows that $E\left(d R^{*}\right)=d R$ when $w_{i}=Y_{i}$. For the semilog specification, the same exercise yields weights $w_{i}=G_{i}$. (Here, given the assumption that the weights are predetermined, one must use a predicted value for $G_{i}$, not its observed value, to avoid bias.) In cases of more targeted tax changes, the weights will be higher for those whose tax rates are particularly affected and lower for others. Though the appropriate weights depend on the specification used and the tax experiment being considered, there is little justification for using sample population weights. These will weight much too heavily individuals with low income and capital gains.

Now, consider the second problem raised above. Suppose one already has the true parameters describing each individual's behavior. The investigator could proceed directly to microeconomic simulations to obtain the correct revenue effects of tax changes. Suppose, however, that he also wished to produce a single, aggregate elasticity that corresponded to this underlying behavior. This is not a superfluous calculation; given the complexities of microeconomic simulation exercises, it is useful to have some idea of how aggregate behavior should look. If, once again, the guiding objective is the accurate estimation of aggregate revenue effects, then one should weight each observation according to the amount of revenue it represents. That is, if one represents the aggregate revenue relationship (equation A.1) in terms of a single overall elasticity $e$, one obtains:

$$
d R=\sum t_{i} G_{i}(e+1) .
$$

For $d R$ as defined in equation A.7 to be correct, the elasticity $e$ must satisfy:

$$
e=\left(\sum t_{i} G_{i} e_{i}\right) /\left(\sum t_{i} G_{i}\right)
$$


In contrast, a simulated elasticity of aggregate gains with respect to a uniform tax change, as reported in the 1985 Treasury panel study, will equal

$$
\left(\sum G_{i} e_{i}\right) /\left(\sum G_{i}\right)
$$

The customary procedure of using sample means to calculate an aggregate elasticity can yield very misleading results. For example, consider again the linear specification, in which $G / Y$ is regressed on the tax rate $t$. Suppose the true model is one in which the coefficient $b$ applies to every individual. Then $e_{i}=-b t_{i} Y_{i} / G_{i}$, and the appropriate aggregate elasticity is, from equation A.8,

$$
\text { (A.10) } e=-b\left(\sum t_{i}^{2} Y_{i}\right) /\left(\sum t_{i} G_{i}\right)=-b\left[\sum\left(t_{i} Y_{i}\right) t_{i}\right] /\left[\sum\left(t_{i} Y_{i}\right) G_{i} / Y_{i}\right] \text {. }
$$

However, the point-of-means elasticity equals:

$$
\bar{e}=-b\left(\sum t_{i}\right) /\left(\sum G_{i} / Y_{i}\right) .
$$

Thus, while the correct procedure involves weighting each tax rate and ratio of gains to income by the product of the taxpayer's tax rate and income, the point-of-means elasticity weights these values equally across taxpayers. The result is that gains and tax rates will be overweighted for individuals with low tax rates or income. The general direction of this bias is ambiguous. If high-income, high-tax-rate, individuals have higher elasticities, the size of the elasticity would tend to be understated. However, including individuals with capital losses and low or zero tax rates in the sample biases the elasticity upward in absolute value; while lower than average nonnegative tax rates receive too much weight in the numerator of expression A.11, negative values are averaged into the denominator-the case discussed in the text. 


\section{Comments and Discussion}

James Poterba: The revenue effect of changes in capital gains taxation is currently one of the most controversial issues in applied public finance. During the past 15 years a barrage of studies by economists in both government and academe has suggested that reducing tax rates may increase capital gains realizations enough to raise the net revenue collected by the capital gains tax. An opposing battery of research suggests otherwise, arguing that while realizations may rise when tax rates fall, the resulting revenue effect is on balance negative. Several new studies have appeared in the past two years, based on aggregate time series modeling of capital gain realizations, but still yielding conflicting results. The debate between these camps has often been fierce, in some cases degenerating to mudslinging attacks on analytical and technical competence that would not have seemed out of place in the recent presidential campaign.

Despite the obvious difficulties of surveying such a contentious literature, Alan Auerbach has risen above the fray and written a firstrate review. I am largely sympathetic to this paper's conclusions, and my remarks will therefore underscore what I view as the paper's contributions to the empirical and theoretical debates surrounding capital gains taxation. I conclude by noting the remaining gaps in our knowledge and where research might reduce our ignorance.

Auerbach's first contribution is to the empirical debate on time series models of capital gains realizations. While most previous studies have examined the link between the level of realized gains and the contemporaneous level of capital gains tax rates, the paper shows that the estimated steady-state effect becomes much smaller when expected tax changes are included in the specification. Controlling for tax changes makes it impossible to reject the hypothesis that in the long run the tax 
level has no effect on realizations, and if forced to choose, the data prefer equations based only on the change in tax rates to specification based only on the level of tax rates. These findings suggest at the very least that existing empirical studies are not robust to minor specifications changes, and they signal the inherently limited information in the time series data.

It is hardly surprising that preannounced changes in the capital gains tax affect investor behavior. Brief reflection on the events surrounding passage of the Tax Reform Act of 1986 illustrates this point. Even a casual reader of the "Personal Investing" column in most newspapers was exposed to simple rules about when to realize gains, and learned that accelerating the sale of assets that he or she planned to sell in the near future would lead to tax savings. My impression of individual taxpayer behavior is that when there is a simple behavioral rule that taxpayers understand and can use to reduce their taxes, they exploit it. Last year the Austrian government changed its tax treatment of families, reducing the tax benefits for couples married after January 1, 1988, by several hundred dollars. During the last few months of 1987, the Austrian marriage rate reached record levels as individuals rushed to qualify for the tax allowance. If taxpayers will distort such decisions as marriage to save on their taxes, I have no doubt they will adjust paper transactions, such as the decision to realize capital gains, in response to obvious tax incentives. The present paper's estimates for the full sample period, including 1986, suggest that an anticipated 1 percentage point increase in the capital gains tax rate from the 1986 level of 0.20 would increase current realizations roughly 15 percent.

Even if the results regarding the long-run effect of the capital gains tax rate on realized gains had been more robust, however, there would be many reasons to be suspicious of the results. Auerbach mentions and corrects some problems, such as the nonstationarity of the relevant variables, but does not discuss others: failure to model the nontax transaction costs of trading, omission of life-cycle or cther variables that might proxy for the demand to realize gains, and relatively weak proxies (such as movements in the stock market) for the accumulated stock of unrealized gains. These factors are likely to change slowly from year to year, thus leading to more important biases in estimates of low rather than high frequency links between capital gains taxes and realizations. The paper's finding that time series results are not robust saves readers the trouble of having to evaluate these other potential biases. 
The new empirical work is not the paper's only contribution. It also calls attention to the critical interactions between the capital gains tax and other parts of the tax structure. Auerbach pushes beyond the naive Lafferesque analysis that if lowering the tax rate on an activity increases the revenue collected by that tax, it is therefore a revenue raiser. Since the capital gains tax is a tax on one type of income, rather than on income per se, and since income is at least partially subject to transfer from one category to another, the capital gains tax rate may affect the revenue yield from other parts of the income tax system. For example, a highearning executive may receive substantial parts of his or her compensation in the form of stock options that yield capital gains, or individuals may borrow heavily to purchase homes, deduct interest payments from ordinary income, and subsequently pay capital gains taxes on home appreciation. In both cases the capital gains tax serves as the "backstop" for the rest of the tax system. When the tax rate is low, taxpayers will expend resources to transform other types of income into capital gains, while at high capital gains tax rates, such transactions are not warranted. Although the possibility that lowering the capital gains tax rate could raise realized capital gains but nevertheless reduce the total revenue take from the personal income tax is sometimes recognized in the writing of tax analysts, it has had virtually no effect on the broader public policy debate. This point needs to be emphasized, and the current paper's discussion is therefore welcome. One might note the implication of this view for empirical models of capital gain realizations. Rather than focusing on just the capital gains tax rate, one should study how the differential between the capital gains rate and other rates affects the mix of reported income.

This paper's central thrust is that aggregate time series models of realized capital gains shed relatively little light on the question of how the capital gains tax rate should be set. True to this theme, Auerbach avoids the inevitable tendency of review writers to conclude with a call for future research. Rather, he calls for a renewed investigation of the policy aims that might be served by cutting the capital gains tax. I would second this call, and note an obvious question that needs attention. Although many call for reductions in capital gains tax burdens on incentive grounds, tax economists regard the effective capital gains tax rate, even at current statutory rates, as lower than most other taxes. Since gains are taxed at realization rather than on accrual, the government effectively provides an interest-free loan on the amount of taxes 
due. For an asset that appreciates at 10 percent a year, the effective tax rate is less than half the statutory rate if the investor's holding period is 10 years. Changes in the statutory rate therefore translate less than onefor-one into changes in effective tax rates. We must learn more about the holding periods of different investors and different assets in order to model their effective tax rates.

I also believe that basic research on why investors realize gains should be given high priority. Models based on life-cycle considerations or on differences of opinion between investors might yield predictions about the level of realized gains. Empirical verification of such models will prove difficult, however, because of fundamental data limitations. Tax return data, which provide detailed information on income, realizations, and tax rates, do not contain data on household wealth or unrealized gains. Most household surveys that contain information on net worth do not include tax return data that permit accurate calculation of marginal tax rates, and most such random surveys have very few respondents in the top 0.5 percent of the income distribution, where most capital gains are realized.

The IRS Capital Gains Tax Panel, spanning several years beginning in 1981 when tax rates changed systematically, may provide some new insights on what determines realized capital gains. But cross-sectional studies encounter problems that time series studies escape. In any year, all taxpayers face the same tax schedule. Conditional on a taxpayer's income, variations in marginal tax rates will largely result from endogenous factors-whether the taxpayer is married or single, whether he or she is a homeowner, and the level of taxes in his or her home state. This endogeneity raises a host of problems in the interpretation of tax elasticities estimated from cross-section data such as the IRS tax files. The systematic tax changes of the 1980s may provide the type of exogenous variation that may ultimately help us to model capital gain realizations, but given the long lags in processing tax return data, such progress may be several years away. In the meantime we should admit the primitive state of our knowledge regarding the long-run influence of capital gains tax changes on income tax receipts.

\section{General Discussion}

Ben Bernanke wondered on what conceptual basis analysts could argue that it is possible to raise total tax revenue by lowering the tax rate 
on capital gains. He observed that any induced shift from income to capital gains actually lowers total revenue when income tax revenues are taken into account. Any shift forward in the timing of capital gains realizations simply shifts tax revenues from the future to the present. And any change in bequest motives could be eliminated by a proper handling of capital gains taxes at death. Auerbach agreed with the thrust of Bernanke's comments, but mentioned two avenues through which revenues conceivably could increase. First, lower capital gains tax rates might reduce tax evasion, an effect James Poterba found to be significant. Second, the present value of tax payments could increase if individuals realize gains more promptly in response to lower rates.

Jane Gravelle was skeptical about the use of cross-sectional econometric evidence to determine the revenue consequences of changing the capital gains tax rate. The primary problem is that, with the exception of tax rate differences across states, variation in the tax rates of individuals is endogenous, reflecting the level of income including capital gains. She also suggested that Auerbach's equation should take into account the fact that realizations come from the "stock" of unrealized gains rather than just the flow of accrued gains in any year. She reported that a CBO study using such an equation found the coefficient on the marginal tax rate to be small, implying a revenue-maximizing tax rate of 50 percent.

Several participants broadened the discussion of capital gains taxation beyond its effect on revenues. George von Furstenberg argued that Auerbach's evidence that the rate on capital gains is already below the revenue-maximizing value contributes to the political debate but should be of little concern to economists. He suggested the important economic question is how to minimize the excess burden associated with a given level of tax revenues. Therefore an analysis of capital gains taxes should focus on the marginal excess burden of the capital gains tax compared with that of other taxes. Von Furstenberg went on to suggest that the internationalization of capital markets makes it likely that the optimal capital gains tax will depend on the taxation of gains in other countries, where rates are lower-sometimes zero.

One of the excess burdens of capital gains taxation identified by Auerbach is the resources expended by individuals as they attempt to delay realizations of capital gains to reduce the present value of tax payments. Alan Blinder questioned Auerbach on proposals mentioned in footnote 48 for a capital gains tax based on realizations but with the 
incentives of a tax based on accrual. He noted that such a tax would eliminate both the incentive to shift realizations and the associated excess burden. Auerbach recalled that nearly 50 years ago William Vickrey proposed a tax system whereby any two individuals with the same income stream but different patterns of realizations would pay the same present value of taxes. Vickrey's system eliminates any incentive to alter the time path of realizing capital gains and has other desirable features as well. It eliminates the penalty that a progressive income tax imposes on high-variance income streams, thus removing a major rationale for treating capital gains, with their high variance, differently from income. Thus the Vickrey system treats earned income and capital gains accruals identically, but introduces no bias against investments with lumpy payoff streams.

To be applied to realized capital gains, Vickrey's scheme would require knowledge of how those gains occurred over time. For many assets, particularly those not actively traded in securities markets, this requirement could represent a problem. Auerbach suggested an alternative scheme that would also provide the incentives of an accrual tax and the convenience of a tax on realizations without requiring information about the pattern of accrued gains, only an asset's final sales price. In place of the actual pattern of accrued gains, the scheme would impute a pattern based on risk-free rates of return available over the same time period. In the working paper cited in footnote 48 , Auerbach had proven that this scheme had the same incentive properties as Vickrey's system. He concluded that proposals such as Vickrey's and his own addressed most of the criticisms of taxation of capital gains accruals, including the liquidity constraints of investors and lack of information on asset values.

Jeremy Bulow suggested an annual property tax or wealth tax as a simpler way to the same end. Rather than taxing capital gains (or losses) as they are generated, wealth could be taxed at a rate that raises a comparable amount of revenue. Such a tax would reduce the variance in taxes paid each year. Furthermore, the problem of measurement error would be reduced because usually wealth can be measured with a much lower percentage error than changes in wealth.

Robert Hall observed that with a fully integrated tax system, there is no need to tax capital gains directly because any capital gains occur on the capitalization of an after-tax income stream. He argued that a tax on business income such as the current corporate income tax is preferable to a tax on gains or assets that are simply claims on that income. 